\section{3. yıla girerken}

\section{Sevgili Meslektaşlarım,}

Sizleri Journal of Medical Updates dergimizin üçüncü cildinde kucaklamaktan mutluluk ve onur duyuyorum.

Başkanlı̆̆ını yaptığım, Sürekli Ĕ̆itim ve Bilimsel Araştırmalar Derneği (SEBAD), adından da anlaşılacağı gibi, eğitim ve bilimsel çalışmaları destekleyen ve kar amacı gütmeyen bir kuruluştur. Birçok bilimsel toplantı düzenledikten sonra, bu dergiyi yılda 3 sayı frekansında yayınlamaya karar verdik.

Dergimiz tüm KBB alanlarının yanı sıra alerji, pediatri, nöroloji, nöroşirürji, anesteziyoloji, radyoloji ve göğüs hastalıkları gibi ilgili alanları da içine alıyor.

Derginin resmi dili Türkçe ve İngilizce'dir. Yazılar bu dillerin birinde yazılmakta ancak özetler her iki dilde de yayımlanmaktadır.

Tüm medikal alanlarda olduğu gibi, otorinolaringoloji ve ilgili uzmanlık alanlarında çok sayıda açık erişim dergiye ihtiyaç bulunmaktadır. Bu ihtiyacın temeli bilgi paylaşımı yapabilmek için sınırların ortadan kaldırılmasıdır. "Journal of Medical Updates" bu amaca hizmet için planlanmıştır. Açık erişim formatında yayın, araştırma kalitesinde lider olmaya aday olmaktan gurur duymaktadır.

Dergimizin dünyanın çeşitli bölgelerinden seçilmiş önde gelen araştırmacılardan oluşan editörleri bulunmaktadır. Nazik destekleri için onlara şükran duymaktayız.

Dergi maceramıza ilk yıl sadece basılı yayın olarak başlasak da, günün koşulları gereği bundan sonraki yayın yolculuğumuza hem basılı, hem de çevrimiçi olarak devam etmeye karar verdik. Artık tüm yayımlanmış tüm makalelere web sitemizden (www.jmedupdates.org) ulaşılabilmektedir. Yazıların açık erişim yayımlanması derneğimizin bir eğitim hizmeti olup, birçok açık erişim dergisinin aksine, yazarlardan hiçbir ücret talep edilmemektedir.

Dergimizin bu emekleme evresindeki titiz çalışmaları ile değerli katkılarda bulunan editor ekibine ve yayımcımız Deomed'e teşekkürlerimi sunuyorum.

Sizi ilk yazınızı "Journal of Medical Updates" dergimize göndermeye davet ediyor, değerlendirme ve son karar sürecinin gerekli titizlikte ama çok kısa olacağına söz veriyorum.

Herhangi bir konuda veya dergimizde yazı değerlendirmek için lütfen benimle temasa geçmekte tereddüt etmeyiniz.

\section{3. year's eve}

\section{Dear Colleagues,}

It is my pleasure and honor to welcome you to the third volume of our journal, "Fournal of Medical Updates".

Continuous Education and Scientific Research Association (CESRA), Turkey, that I chair, is a nonprofit organization that aims to supports education and scientific research as indicated in its name. After setting various scientific meetings, we have decided to publish this journal initially as three issues per year. Besides all ENT topics, it also covers related specialties of ENT such as allergy, pediatrics, neurology, neurosurgery, anesthesiology, radiology, pulmonology and etc.

The formal languages of the journal are both English and Turkish. Papers written at either language have abstracts in both.

In the fields of otorbinolaryngology and related specialties, as in all medical fields, there is a need for a greater number of journals which publish in the open access format. The underlying spirit of this format is to break down the barriers to knowledge sharing.

"Fournal of Medical Updates" was created to serve this need; and is proud to be the candidate to take the lead in publishing quality research work as an experiment in the open format.

Our journal has a distinguished editorial board composed of leading surgeons and researchers from around the world. We are very thankful to them for their kind contribution.

Although we have started this adventure as a printed only journal in 2011, we decided to continue this journal both in print and online. All articles are available at our website (www.jmedupdates.org) as an open access journal. It is completely free to publish your scientific work bere, on the contrary of most open access journals.

Many thanks to our editorial team and our publishers for their genuine effort in growing of our journal.

I would like to invite you to submit your latest manuscripts to fournal of Medical Updates. I promise a fast but meticulous review and final decision.

Please do not hesitate to contact me if you bave any questions about the journal or to volunteer to be a reviewer.

Best regards,

Cemal Cingi, MD

Editor-in-Chief 